\title{
EFFECT OF MARKET PARTICIPATION ON FOOD SECURITY AMONG SMALLHOLDER SORGHUM FARMERS IN KWARA STATE, NIGERIA
}

\author{
M.F. SALAMI ${ }^{1, *}$, K.K. OSASONA ${ }^{1}$, G.O. AKINSOLA ${ }^{1}$, \\ S.U.O. AKANBI ${ }^{1}$, M.T. DUROSAYE ${ }^{1}$ \\ *E-mail: markmercy12@gmail.com
}

Received: Apr. 03, 2020. Revised: June 18, 2020. Accepted: June 26, 2020. Published online: Oct. 16, 2020

\begin{abstract}
It is paradoxical to note that food insecurity remains a menace among many African farmers' households. There are arguments for and against smallholder farmers' market participation as a pathway for ensuring household food security. The paper therefore examined the market participation- food security relationship using smallholder sorghum farmers in Kwara State, as a case study. Primary data were obtained from 112 sorghum farming households using the semi-structured interview survey method. Descriptive statistic (frequencies and percentages), Crop output market participation index, Logistic regression model and Tobit regression model was used to analyse the data obtained. The result revealed that market participation positively and significantly contributes to the food security status of the sorghum farmers. Also, household size, farm output quantity, access to market information, access to credit and farm power types were the factors influencing the level of
\end{abstract}

market participation in the study area. Therefore, all factors that will aid farmers' market participation should be pursued.

Keywords: food insecurity; tobit regression; farm output; credit.

\section{INTRODUCTION}

Agriculture is an occupation that is intimately linked with food security, health, and nutrition through direct consumption and market linkages (Poole, 2017). However, in spite of the close relationship between agriculture and nutrition, most of the undernourished people in the world are smallholder farmers (Frelat et al., 2016). Agricultural pathways, such as crop diversity and market participation, have been identified to be beneficial for improving food security among smallholder farmers.

\footnotetext{
1 Department of Agricultural Economics and Farm management, Faculty of Agriculture, University of Ilorin, Nigeria
} 


\section{MARKET PARTICIPATION - FOOD SECURITY NEXUS}

Market participation is defined as involvement in any market-related activity that promotes the sale and purchase of agricultural produce (Adeoti et al., 2014). It simply involves agricultural commercialization by food producers leading to the creation of an output market for intermediaries and consumers to access and buy. The participation of smallholder farmers in marketing is very important, as it is the major determinant of a better household income and sustainable livelihoods (Kyaw et al., 2018).

In recent times, researchers have focused attention on the linkages between agricultural market participation and household income. This study, therefore, seeks to analyse the effect of market participation on food security among sorghum farmers in Kwara State using quantitative methods and models. Given the foregoing, this study sought to answer the following research questions: What is the level of crop output market participation among the sorghum farmers in the study area ? What are the factors that influence the level of crop output market participation by smallholder sorghum farmers in the study area? What is the effect of crop output market participation by smallholder sorghum farmers on their food security status?

\section{MATERIALS AND METHODS}

\section{Study area}

The study was conducted in Kwara State, which lies between latitudes $7^{\circ} 45^{\prime} \mathrm{N}$ and $9^{\circ} 30^{\prime} \mathrm{N}$ and longitudes $2^{\circ} 30^{\prime} \mathrm{E}$ and $6^{\circ} 25^{\prime} \mathrm{E}$ and covers a total land area of about $332,500 \mathrm{~km}^{2}$ with estimated figures of about 102,969 farms (Fig. 1).

It is located in the agro-ecological zone of the country, with a population of about 2.37 million.

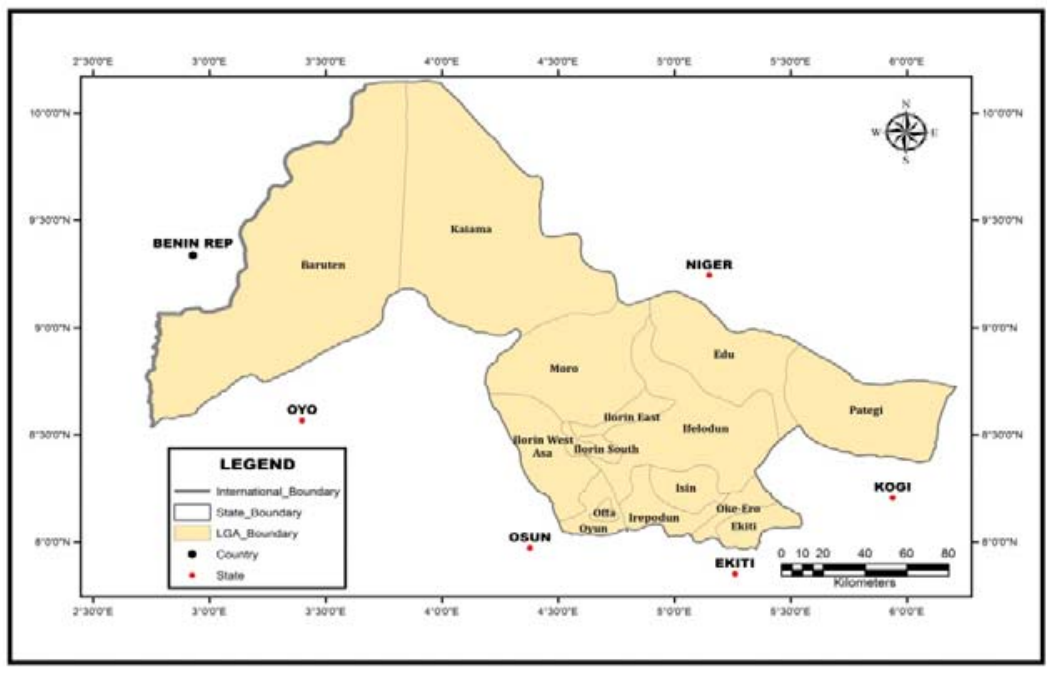

Figure 1 - Map of Kwara State 


\section{M.F. SALAMI, K.K. OSASONA, G.O. AKINSOLA, S.U.O. AKANBI, M.T. DUROSAYE}

The main crops planted are sorghum, maize, cassava, groundnut, soybean, wheat, sweet potato, cowpea, yam, pepper, and vegetables. The state is divided into four agro ecological zones by the Kwara State Agricultural Development Project (Zone A, B, C, D). The study relies on the Food and Agriculture Organization (FAO) definition of small holder farmers. Smallholders are small-scale farmers, pastoralists, forest keepers, fishers, who manage areas varying from less than 1 ha to 10 ha.

\section{Sampling technique}

A four-stage sampling technique was used in the study. The first stage involved the random selection of two ADP zones ( $C \& D$ ) from the four ADP zones of Kwara State. Second was the random selection of one local government area (LGA) from each of the two zones. The local government areas selected were Ifelodun and Ilorin East LGAs. The third stage was the random selection of four villages from each LGA. At the last stage, a snowballing technique was used to generate a list of smallholder sorghum farmers in each of the selected villages; 14 smallholder sorghum farming households were then randomly selected from each of the eight selected villages making a total of 112 farming households.

\section{Source of data}

Primary data was collected with the aid of a semi structured interview in the farmers' local language. This is because most of the farmers have little or no years of formal education.

\section{Analytical technique}

The study used the market participation index, as used by Demeke and Haji (2014) to classify the farmers into high, medium and low levels of commercialization. The index is expressed as follows:

$$
M P_{i t}=\frac{\sum P_{k} S_{i k}}{\sum P_{k} Q_{i k}}
$$

where, $S_{i k}$ is the quantity of output $k$ sold by household $i$, evaluated at an average community price $P_{k} Q_{i k}$ is the total value of output $k$ produced by household $i$; crop output market participation level ( $\left.\mathrm{MP}_{\mathrm{it}}\right)$.

Crop output market participation $\left(\mathrm{MP}_{\mathrm{it}}\right)$ was grouped into three levels: 1. Subsistence farmers (value of the sale is less than 25\%); 2. Transition farmers (value of sale between $25 \%$ - 50\%); 3 . Commercial farmers (value of sale greater than $50 \%$ ). Following the methodology of Oluwatayo and Rachoene (2017), the logistic regression model was used to analyse the effect of market participation on the food security status of the smallholder sorghum farmers in the study area.

$$
Y_{i t}=\beta_{0}+\beta_{1} M_{i t}+\beta_{2} X_{2}+\beta_{i} X_{i t}+\mu_{i t} \quad i=1, \ldots \ldots, N
$$

$\beta_{0}=$ Intercept; $\beta_{i t}=$ Regression coefficient; $Y_{i t}=$ The food security status of household; $\mathrm{X}_{1}=$ Age of the household head (years); $X_{2}=$ Gender of the household head ( 1 if male and 0 if otherwise); $\mathrm{X}_{3}=$ Years of schooling; $\mathrm{X}_{4}=$ Household size (Number of household members); $X_{5}=$ Farm size in hectares; $\mathrm{X}_{6}=$ Quantity produced $(\mathrm{kg}) ; \mathrm{X}_{7}=$ Access to market information (yes $=1$, no $=0$ ); $\mathrm{X}_{8}=$ Off farm income (Naira); $\mathrm{X}_{9}=$ Access to credit (yes $=1$, no $=0) ; X_{10}=$ Distance to the main market $(\mathrm{km}) ; \mathrm{X}_{11}=$ Ownership of transport equipment (yes $=$ 1, no $=0) ; X_{12}=$ Farm power type $($ Mechanized $=1$, otherwise $=0) ; X_{13}=$ Crop output market participation level $(<25 \%=$ low, $26-50 \%=$ medium, $>50 \%$ 


\section{MARKET PARTICIPATION - FOOD SECURITY NEXUS}

$=$ High); $\mu_{\mathrm{it}}=$ Error term, where, $\mathrm{Y}_{\mathrm{it}}$ is the food security status of household $i$ at time $t$, and $\mathrm{MP}_{\text {it }}$ is the crop output market participation level; $X_{i t}$ is the characteristics of the farming household observed and $\mu_{\mathrm{it}}$. The study relied on daily energy consumption/adult male equivalent to assess the food security status ( $\mathrm{Y}_{\text {it }}$ ) households observed.

Tobit model was used to analyse the factors that influenced crop output market participation level among sorghum farmers in the study area.

$$
\begin{gathered}
Y^{*}=\beta 0+\beta 1 X 1+\beta 2 X 2+\ldots+\beta i X i+\mu i \quad i=1, \ldots, N \\
Y=0 \text { if } y \leq 0, y=Y^{*} \text { if } y>0 .
\end{gathered}
$$

$Y^{*}=$ crop output market participation index; $\beta=$ estimated parameter or coefficient; $\mathrm{Xi}=$ the explanatory variables; $\mu \mathrm{i}=$ error term and is normally distributed with zero mean and constant variance; $X_{1}$ $=$ Age of the household head (years); $X_{2}=$ Gender of the household head (1 if male and 0 otherwise); $X_{3}=$ Years of schooling; $\mathrm{X}_{4}=$ Household size (Number of household members); $X_{5}=$ Farm size in hectares; $X_{6}=$ Quantity produced $(\mathrm{kg}) ; X_{7}$ $=$ Access to market information (yes $=1$, no $=0) ; X_{8}=$ Off-farm income (Naira); $X_{9}$ $=$ Access to credit $(\mathrm{yes}=1$, no $=0) ; \mathrm{X}_{10}=$ Distance to the main market $(\mathrm{km}) ; \mathrm{X}_{11}=$ Ownership of transport equipment (yes $=$ 1 , no $=0) ; \mathrm{X}_{12}=$ Farm power type (Mechanized $=1$, otherwise $=0)$.

\section{RESULTS AND DISCUSSION}

The estimates of the levels of participation were used to classify the sorghum farmers into low, medium and high commercial farmers. Table 1 shows that most (52.68) of the sorghum farmers were found to highly commercialize, while farmers that have a low and medium level of crop output market participation constitute $16.96 \%$ and $30.36 \%$, respectively. This implies that the level of crop output market participation is high among the smallholder sorghum farmers.
Table 1 - Crop output market participation level of sorghum farmers

\begin{tabular}{lc}
\hline Level & $\begin{array}{c}\text { Percentage } \\
(\mathrm{n}=112)\end{array}$ \\
\hline Low $(<25 \%)$ & 16.96 \\
\hline Medium $(26 \%-50 \%)$ & 30.36 \\
\hline High $(>50 \%)$ & 52.68 \\
\hline Total & 100 \\
\hline \multicolumn{2}{c}{ Source: Field survey }
\end{tabular}

From the result of the logistic regression statistic in Table 2, the gender of the household head is found to have a negative relationship with food security. This implies that the female headed households were more food secured that their male headed counterparts. Also, the level of crop output market participation has a positive and significant relationship with household daily calorie consumption at 5\%, which implies that market participation of sorghum farmers tends to foster household food security. This implies that the higher the level of crop output market participation level, the higher the level of food security of the smallholder sorghum farmer. This contradicts Oluwatayo and Rachoene (2017), who assessed the effect of level of crop commercialization on food 
security in South Africa and found it to be negatively significant to food security at $5 \%$.

Household size was also found to be negatively significant at all levels. This implies that the larger the household size, the lesser the tendency of the household being food secured. This is in tune with prior expectations, as research as established a negative relationship between household size and food security.

Table 2 - Effect of crop output market participation level on the food security status of farmers

\begin{tabular}{llcc}
\hline \multicolumn{1}{c}{ Variables } & Coefficients & Standard error & $\mathbf{Z}$ \\
\hline Age of household head & 0.0228402 & 0.0247108 & 0.92 \\
\hline Gender of the household head & $-1.90444^{\star *}$ & 0.9667746 & -1.97 \\
\hline Years of schooling & -0.0601861 & 0.0584024 & -1.03 \\
\hline Household size & $-0.3392041^{\star * *}$ & 0.1156818 & -2.93 \\
\hline Farm size & -1.251259 & 0.7184771 & -1.74 \\
\hline Output quantity & 0.0002753 & 0.0002347 & 1.17 \\
\hline Access market information & -0.8432886 & 0.6832836 & -1.23 \\
\hline Off farm income & $-7.09 \mathrm{e}-06$ & $9.17 \mathrm{e}-06$ & -0.77 \\
\hline Access to credit & 0.4699395 & 0.5358007 & 0.88 \\
\hline Distance to market $(\mathrm{km})$ & -0.0562584 & 0.029727 & -1.89 \\
\hline $\begin{array}{l}\text { Transportation } \\
\text { (ownership of transportation assets) }\end{array}$ & 0.6427257 & 0.5772307 & 1.11 \\
\hline Farm power type & & & \\
\hline Level of market participation & -0.0966582 & 0.3194899 & -0.30 \\
\hline Constant & $0.0328986^{* *}$ & 0.0145318 & 2.26 \\
\hline Number of obs. $=112$ & 2.739164 & 1.91011 & 1.43 \\
\hline Log likelihood $=-55.138345$ & & & \\
\hline Pseudo ${ }^{2}=0.2729$ & & & \\
\hline
\end{tabular}

Source: Field survey: at $1 \%^{* * *}$; at $5 \%^{* *}$

As shown in the Table 3, the result from the Tobit regression model revealed that household size significantly (at 5\%) and negatively affects market participation. This implies that the larger a farmer's household size, the lower his tendency of involvement in market participation. This is probably because a larger household requires more quantity of food for survival than smaller households. This would negatively affect the quantity of food output available for participating in the market. However, this contradicts my expectations and Abdullah et al. (2017), who suggested that large household size increases output commercialization because of the advantage of family labour. Besides, output quantity was found to be positively significant at $1 \%$. This conforms to a priori expectation. According to Abdullah et al. (2017), higher output increases the marketable surplus and thereby increases the intensity of market participation. 
The result also revealed that access to market information positively and significantly (at 1\%) affects market participation. This which means that sorghum farmers, who have access to market information in the study area, tend to engage more in crop output market participation. Access to credit was positively significant at $5 \%$. This implies that access to credit by sorghum farmers aids easy access to farm inputs to produce a marketable surplus. Farm power type was also found to be positively significant at $5 \%$, this is probably because about $56 \%$ of the farmers utilize draught and tractors to plough their land. Farmers that make use of draught and tractor are more likely to produce larger marketable surplus than those that are human labour dependent.

Table 3 - Determinants of crop output market participation by the sorghum farmers

\begin{tabular}{llccc}
\hline Variables & Coefficients & $\begin{array}{c}\text { Standard } \\
\text { error }\end{array}$ & $\mathbf{t}$ & P> t \\
\hline Age household head & -0.2786104 & 0.1784567 & -1.56 & 0.122 \\
\hline $\begin{array}{l}\text { Gender of the } \\
\text { household head }\end{array}$ & 5.473923 & 6.534986 & 0.84 & 0.404 \\
\hline Year of schooling & -0.523541 & 0.4225965 & -1.24 & 0.218 \\
\hline Household size & $-1.208268^{* *}$ & 0.4871939 & 2.48 & 0.015 \\
\hline Farm size & 3.714107 & 3.174948 & 1.17 & 0.245 \\
\hline Output quantity $(\mathrm{kg})$ & $0.006814^{* * *}$ & 0.000068 & 4.94 & 0.000 \\
\hline $\begin{array}{l}\text { Access to market } \\
\text { information }\end{array}$ & $19.73274^{* * *}$ & 4.966485 & 3.97 & 0.000 \\
\hline Off farm income & 0.0000256 & 0.000068 & 0.38 & 0.708 \\
\hline Access to credit & $8.368604^{* *}$ & 3.84787 & 2.17 & 0.032 \\
\hline Distance to market & -0.1159539 & 0.2161936 & -0.54 & 0.593 \\
\hline $\begin{array}{l}\text { Transportation } \\
\text { (ownership of } \\
\text { transportation assets) }\end{array}$ & 0.760702 & 3.97767 & 0.19 & 0.849 \\
\hline Farm power type & $4.791925^{* *}$ & 2.201403 & 2.18 & 0.032 \\
\hline Constant & 28.22488 & 13.54047 & 2.08 & 0.040 \\
\hline Sigma & 17.93277 & 1.269413 & & \\
\hline Number of obs $=112$ & & & & \\
\hline LR chi2(12) $=81.32$ & & & & \\
\hline Prob $>$ chi2 = 0.000 & & & & \\
\hline
\end{tabular}

Source: Field survey; at $1 \%^{\star * *}$; at $5 \%^{* *}$

\section{CONCLUSION AND RECOMMENDATION}

The study revealed that market participation is positively and significantly linked to household food security among small holder sorghum farmers in Kwara State, Nigeria.
Hence, the higher the level of crop output market participation, the better the food security level of the smallholder sorghum farmers. It is therefore recommended that efforts that will result in increased market participation among smallholder 
sorghum farmers should be put in place by all relevant stakeholders.

\section{REFERENCES}

Abdullah, Rabbi, F., Ahamad, R., Ali, S., Chandio, A.A., Ahmad, W., llyas, A. \& Ud Din, I. (2017). Determinants of commercialization and its impact on the welfare of smallholder rice farmers by using Heckman's twostage approach. J. Saudi Soc.Agric. Sci., 18(2): 224-233, DOI: 10.1016/ j.jssas.2017.06.001

Adeoti, A.I., Oluwatayo, I.B. \& Soliu, R.O. (2014). Determinants of market participation among maize producers in Oyo State, Nigeria. BJEMT, 4(7): 1115-1127, DOI: 10.9734/BJEMT/2014/7826

Demeke, L. \& Haji, J. (2014). Econometric analysis of factors affecting market participation of smallholder farming in Central Ethiopia. J.Agric.Econ.Ext.Rural Dev., 6(2): 094-104.
Frelat, R., Lopez-Ridaura, S., Giller, K.E., Herrero, M., Douxchamps, S., Djurfeldt, A.A. et al. (2016). Drivers of household food availability in sub-Saharan Africa based on big data from small farms. Proc.Natl.Acad.Sci.USA, 113(2): 458-463, DOI: 10.1073/pnas. 151838 4112

Kyaw, N.N., Ahn, S. \& Lee, S.H. (2018). Analysis of the factors influencing market participation among smallholder rice farmers in Magway Region, Central Dry Zone of Myanmar. Sustainability, 10(12): 4441, DOI: 10.3390/su10124441

Oluwatayo, I.B. \& Rachoene, M.A. (2017). Effect of agricultural commercialization on food security among smallholder farmers in Polokwane municipality, Capricorn District of Limpopo Province, South Africa. J.Agric.Rural Dev., 43(1):143156, DOI: 10.22004/ag.econ.259682

Poole, N. (2017). Smallholder agriculture and market participation. Rugby; Rome: Practical Action Publishing; FAO, 172 p., DOI: 10.3362/978178 0449401. 